IZA DP No. 8676

Gender Bias in Tax Systems Based on Household Income

Yuri Andrienko

Patricia Apps

Ray Rees

November 2014 


\title{
Gender Bias in Tax Systems Based on Household Income
}

\author{
Yuri Andrienko \\ Sydney University Law School \\ Patricia Apps \\ Sydney University Law School \\ and IZA \\ Ray Rees \\ University of Munich, \\ University of Warwick and CESifo
}
Discussion Paper No. 8676
November 2014

\author{
IZA \\ P.O. Box 7240 \\ 53072 Bonn \\ Germany \\ Phone: +49-228-3894-0 \\ Fax: +49-228-3894-180 \\ E-mail: iza@iza.org
}

Any opinions expressed here are those of the author(s) and not those of IZA. Research published in this series may include views on policy, but the institute itself takes no institutional policy positions. The IZA research network is committed to the IZA Guiding Principles of Research Integrity.

The Institute for the Study of Labor (IZA) in Bonn is a local and virtual international research center and a place of communication between science, politics and business. IZA is an independent nonprofit organization supported by Deutsche Post Foundation. The center is associated with the University of Bonn and offers a stimulating research environment through its international network, workshops and conferences, data service, project support, research visits and doctoral program. IZA engages in (i) original and internationally competitive research in all fields of labor economics, (ii) development of policy concepts, and (iii) dissemination of research results and concepts to the interested public.

IZA Discussion Papers often represent preliminary work and are circulated to encourage discussion. Citation of such a paper should account for its provisional character. A revised version may be available directly from the author. 
IZA Discussion Paper No. 8676

November 2014

\section{ABSTRACT}

\section{Gender Bias in Tax Systems Based on Household Income*}

The assumption that household income is strongly and positively correlated with a household's real standard of living provides the basis for the joint taxation of families, which has the effect of discriminating against married women as second earners. This paper shows, in the context of a model of the household with young children present, that this assumption is not tenable. The fact that there is considerable heterogeneity in female labour supply which cannot be explained by wage rates and the number and ages of children requires us to look for other explanations, and we argue that these can be found in the variation of child care costs and productivities across households. When these are taken into account, we show, by theoretical modelling and numerical simulations based on survey data, that household income is a poor indicator of household well-being.

JEL Classification: H24, H31, J13, J16, J22, D13

Keywords: gender, discrimination, household taxation, child care, female labour supply, household production, inequality

Corresponding author:

Patricia Apps

Faculty of Law

University of Sydney

NSW 2006

Australia

E-mail: patricia.apps@sydney.edu.au

\footnotetext{
* The research was supported under the Australian Research Council's Discovery Project funding scheme (DP1094021).
} 


\section{Introduction}

A central issue in the design of tax and transfer policies is the choice of a measure of income as the tax base that is strongly correlated with household welfare. This is not straightforward because most adults of working age live as couples. If all couples with the same wage rates were observed to make the same labour supply decisions, we might reasonably expect household income, deflated by an appropriate equivalence scale, to track the living standards of couples. However, survey data indicate a high degree of heterogeneity in the labour supply of the "secondary" earner (typically the female partner on a lower wage) after the first child, at given wage rates and demographic characteristics.

Prior to having children there is very little difference between male and female labour supplies - both tend to work full time. ${ }^{1}$ This can change dramatically with the arrival of children because they create an additional work choice, that of working at home providing child care as an alternative to working in the market and buying in care and related services. In the vast majority of households the male partner continues to work full time while, in many OECD countries, around a third of married mothers allocate their time entirely to home production and an almost equal proportion to full time market work. A fundamental limitation of household income as a measure of welfare is that it omits the contribution of the former to family welfare, that is, it implicitly equates this to zero.

In some countries, notably the US, France and Germany, the formal income tax system is based on joint income. ${ }^{2}$ Others, including Australia and the UK, have a system of "quasi-joint" taxation: though the formal tax system is based on individual income, family benefits, as in Australia, or "in work" income support payments, as in the UK, are withdrawn on the basis of household income. ${ }^{3}$ There is an established literature which argues against joint taxation on the grounds that it discriminates against working married women by imposing the same tax burden and marginal tax rate on families with the same joint income but different allocations of time to untaxed home production. ${ }^{4}$ Both the efficiency and distributional advantages of an individual income tax arise from marginal rate independence. Under a progressive rate scale the second earner typically faces a lower marginal rate, and therefore a two-earner household pays less tax than a single-earner household with the same joint income. ${ }^{5}$

\footnotetext{
${ }^{1}$ See the life cycle model in Apps and Rees (2010). For further empirical evidence for Australia, Germany, the UK and US, see Apps and Rees (2009).

2 The US and Germany have a simple "income splitting" system in which taxation is based on income per adult member of the household while the French system includes the number of children in the income splitting formula.

${ }^{3}$ Income targeting on the basis of joint income not only changes the tax base, it can also replace a progressive rate scale with an inverted U-shaped scale. Under the Australian system a married mother who decides to go out to work can face an effective marginal tax rate that is well above the top formal rate on income, see Apps and Rees (2009, Ch.6).

${ }^{4}$ See for example, the critique of joint filing under the US Federal Income Tax in Feldstein and Feenberg (1996), Munnell (1980) and Rosen (1977).

${ }^{5}$ The efficiency argument for individual taxation is well established. The fact that male and female labour supply elasticities differ considerably argues for individual taxation on standard
} 
In contrast to this view, there are a number of economists who still see the issue of taxing couples as one of dealing with the alleged incompatibility of three policy goals: marriage neutrality, progressivity and equal taxation of equal household incomes. For example, the recent Mirrlees Review of the UK tax system states: ${ }^{6}$

"To be neutral with respect to whether two individuals form a couple or not, the tax and benefit system would have to treat them as separate units. But to treat all couples with the same combined income equally, the tax and benefit system would have to treat couples as a single unit. If an individualized system is progressive, so that the average tax rate rises with income, then two couples with identical joint incomes but different individual incomes would pay different amounts of tax.[...] A tax system cannot simultaneously be progressive, neutral towards marriage/cohabitation, and tax all families with the same joint income equally."

The Review recommends individual income as the base of the formal income tax but the withdrawal of family payments on joint income, in other words, a system of "quasi-joint" taxation. In many OECD countries, the last three to four decades have seen socioeconomic changes and the introduction of antidiscrimination legislation that have contributed towards reducing the gender pay gap. It is therefore something of a paradox that in several of those countries an increase in the effective gender wage gap has been introduced, or is proposed for the future, through their family tax and transfer systems. ${ }^{7}$ This policy direction is also a puzzle in the light of the work of Becker (1965) and subsequent studies on the economics of the family and household production. ${ }^{8}$

In this paper we trace the perception driving this policy direction, that household income is a reliable measure of family welfare, to assumptions underpinning much of the vast literature on family labour supply models estimated on data sets with missing information on the productivity of home time. The convention is to assume implicitly, and unrealistically, that the productivity of an hour of home time is constant across all households. ${ }^{9}$ We construct simulations based on a model that specifies an explicit household production system to show that this convention, together with the usual assumptions on market productivity and prices, generates a monotonic relationship between family welfare and household income, and therefore implies that work at home does not contribute significantly to family welfare. We then show that the relationship no longer holds under more plausible productivity assumptions. The analysis

Ramsey grounds, as discussed in Rosen (1977), Munnell (1980) and Boskin and Sheshinski (1983).

${ }^{6}$ Mirrlees et al. (2011).

${ }^{7}$ Reducing "outside" opportunities, by lowering the net-of-tax second wage, can also be expected to support within-household inequality if, as argued in Apps (1982), the gender wage gap impacts on the terms of exchange within the household. See also Apps and Rees (1988, 2009).

${ }^{8}$ For a survey of this literature, see Apps and Rees (2009, Chs. 2-4).

${ }^{9}$ The assumption of constant productivity across all households is contradicted by studies that find a positive relationship between child outcomes and parental human capital. See, for example, Lundborg et al. (2012) and for a survey, see Almond and Currie (2011). 
focuses on child care as the canonical form of household production.

The paper is organised as follows. Section 2 presents our general theoretical model and the empirical specification used in the simulations. Section 3 discusses household survey data for earnings and labour supplies on which the simulations are based. Section 4 gives the details of the simulations and presents the results. Section 5 concludes.

\section{The Model}

In the standard 2-person model of family labour supply, household utility is defined on consumption and two leisures, male and female. The model is typically estimated on a data set with information on household labour supplies and wage rates but with no information on the quality or productivity of "leisure", measured as time allocated to non-market activity including child care. The convention of setting the price of each partner's leisure to the respective wage rate simultaneously sets the quality of an hour of leisure, and therefore the productivity of an hour of home child care, to a constant across all households. ${ }^{10}$ It is also a convention to define consumption as a Hicksian composite good with a price normalised to one. ${ }^{11}$ Many studies then go on treat expenditure on bought in child care and related substitute services for home time as a component of the Hicksian good also priced at one. ${ }^{12}$

The high degree of heterogeneity at given wage rates that is inevitably left unexplained in a model of this kind is attributed to preference heterogeneity, captured by error terms on estimated coefficients. Welfare comparisons are therefore ruled out. The modelling approach is frequently justified as the only feasible option given missing data on household production. Our aim here is to present a model in which the underlying assumptions become more transparent and therefore more open to debate. For this purpose we assume identical preferences and formulate a model in which heterogeneity of labour supply choices can be driven by production parameters, productivities or prices. This allows us to make direct comparisons of household income and household welfare.

\subsection{Theoretical Framework}

We define child care broadly, to denote not just physically looking after the child, but rather all the activities and bought in services that contribute to the

\footnotetext{
${ }^{10}$ As emphasised by Stern (1976), this assumption is entirely arbitrary and changing it, for example by allowing quality to rise with the wage, can change estimated elasticities. For further discussion and alternative formulations of the 2-person labour supply model, see Apps and Rees (2009, Ch. 4).

${ }^{11}$ For the standard formulation of the model of "family labour supply", and subsequent overview of alternative empirical approaches, see the Blundell and Macurdy (1999) survey of the labour supply literature. The same convention appears in the formulation of "collective" models, including those that explicitly introduce household production, as, for example, in Blundell et al. (2005).

${ }^{12} \mathrm{See}$, for example, the empirical application and extension of the Blundell et al. (2005) "collective" model with household production in Cherchye et al. (2012).
} 
child's welfare and development of human capital, that is, to "child outcomes".

There is a composite market consumption good, $x$, with a price, $p_{x}$, normalised to one. Within the household there are a primary earner with labour market income $y_{1}$ and a second earner with income $y_{2}$, where $y_{1} \geq y_{2}$, facing given wage rates $w_{1}$ and $w_{2}$, respectively, where $w_{1} \geq w_{2}$, representing productivity in a linear aggregate production technology that produces $x$. The key household decision is the second earner's allocation of time between market work and home child care. To focus on this decision we assume that the labour supply and income of the primary earner are fixed. We also assume that only the second earner supplies time to home child care and that her leisure is fixed and normalised at zero. We denote the second earner's labour supply by $l$.

The utility function of household $h=1, \ldots n$ is defined on the household's consumption $x_{h}$ and child care $z_{h}$, that is, we have

$$
u_{h}=u^{h}\left(x_{h}, z_{h}\right)
$$

where $u^{h}($.$) is strictly quasiconcave and increasing. { }^{13}$

Child care is the output of a household production system given by the linear homogeneous production function

$$
z_{h}=f^{h}\left(k_{h} t_{h}, q_{h} b_{h}\right)
$$

where $t_{h}$ is the second earner's child care time, $b_{h}$ is bought in child care time, $k_{h}$ is the exogenously given productivity of home child care and $q_{h}$ the quality of bought in child care chosen by the household. Given the results of studies on factors contributing to child outcomes, $k_{h}$ can be expected to reflect the human capital of the second earner and the resources available to the household.

For the second earner, the time spent in market work, $l_{h}$, and child care time, $t_{h}$, must sum to the total time endowment, normalised at 1 , and so we have

$$
t_{h}=1-l_{h}
$$

There is a further time constraint. Although second earner and bought-in child care time inputs may not be perfect substitutes in producing child care, realistically it is the case that every hour the second earner spends at work ${ }^{14}$ requires an hour of bought in child care, in which case

$$
b_{h}=l_{h}
$$

\footnotetext{
${ }^{13}$ Note that, although it would be easy to do, nothing would be gained by specifying a "collective" model with a sharing rule defined on wage rates and nonlabour income because there is an inherent information asymmetry. When we cannot observe home productivity it follows that we cannot observe the quantity of output exchanged within the household and therefore the implicit earnings (and saving) of a partner specialising in home production.

${ }^{14}$ It seems reasonable to assume for simplicity that the second earner's hours at work are "nested" in those of the primary earner, so that the demand for bought in child care is essentially driven by the second earner's market labour supply. Though empirically more complicated cases are possible we do not think much would be gained by taking them into account in this paper.
} 
Note that, as with any binding constraint, this will imply that the household in general achieves a lower level of optimised utility than if it did not exist. As we show in equation (8) below, it also implies that the familiar efficiency condition from standard labour economics, that marginal value productivity of labour is equated to the wage rate, no longer holds, and we obtain a modified condition that shows how important the price and productivity of non-parental child care are to a household in which the second earner has a positive market labour supply.

Given that $y_{2 h}=w_{2 h} l_{h}$, we can write the budget constraint as

$$
x_{h}+p_{h} b_{h} \leq y_{1 h}+w_{2 h} l_{h}
$$

implying, from (4)

$$
x_{h} \leq y_{1 h}+\left(w_{2 h}-p_{h}\right) l_{h}
$$

where $p_{h}$ is the price to household $h$ of an hour of bought in care at its chosen quality $q_{h}$ and $w_{2 h}-p_{h} \gtreqless 0$ is the net return to an hour of market work. We assume $p_{h}=p\left(q_{h}\right)+\tilde{\varepsilon}$, with $p^{\prime}()>0,. p^{\prime \prime}() \geq$.0 , so that price of bought in child care is a convex increasing function of its quality. Households choosing the same quality may however pay a different price due to exogenous stochastic price variation across households, represented by the random variable $\tilde{\varepsilon} \gtreqless 0$. Note however the household is assumed to know its own realisation of $\tilde{\varepsilon}$ when it solves its choice problem, i.e. it does not face uncertainty.

To focus on essentials it is useful to use the time constraints $t_{h}+l_{h}=1$ and $b_{h}=l_{h}$ to write the household's maximisation problem as

$$
\max _{x_{h}, l_{h}, q_{h}} u^{h}\left(x_{h}, f^{h}\left(k_{h}\left(1-l_{h}\right), q_{h} l_{h}\right) \text { s.t. } x_{h} \leq y_{1 h}+\left(w_{2 h}-p\left(q_{h}\right)-\varepsilon_{h}\right) l_{h}\right.
$$

where $\varepsilon_{h}$ is the realisation of $\tilde{\varepsilon}$ for household $h$. This focuses on second earner labour supply and the structure of household production. From the first order conditions for this problem (assuming an interior solution) we derive the condition

$$
\frac{u_{z}^{h}}{\lambda_{h}}\left(f_{1}^{h} k_{h}-f_{2}^{h} q_{h}^{*}\right)=w_{2 h}-p_{h}^{*}
$$

with $q_{h}^{*}$ the optimal quality of bought in care and $p_{h}^{*}=p\left(q_{h}^{*}\right)+\varepsilon_{h}$. The left hand side gives the difference in marginal value products of $t_{h}$ and $b_{h}$ respectively, expressed in terms of the numeraire, consumption, and the right hand side gives the net return to a unit of $l_{h}$, also in terms of the numeraire. The term $f_{1}^{h} k_{h}-f_{2}^{h} q_{h}^{*}$ reflects the fact that a small increment in the second earner's time in child care increases $z_{h}$ by $f_{1}^{h} k_{h}$ but, since this means that correspondingly less of the market child care needs to be bought, output is reduced by $f_{2}^{h} q_{h}$. Thus this term gives the net effect of a small change in second earner labour supply on $z_{h}$.

Note that the model does not exclude an equilibrium in which $w_{2 h}<p_{h}^{*}$ so that the return to market labour supply is negative, as long as at the equilibrium 
$f_{2}^{h} q_{h}>f_{1}^{h} k_{h}$, the higher marginal productivity of bought-in as opposed to the second earner's child care makes this worth while. ${ }^{15}$

The indirect utility function is $v^{h}\left(w_{2 h}-p_{h}^{*}, y_{1 h}, k_{h}, \varepsilon_{h}\right)$, with, by the Envelope Theorem

$$
\frac{\partial v^{h}}{\partial\left(w_{2 h}-p_{h}^{*}\right)}=\lambda_{h} l_{h}, \quad \frac{\partial v^{h}}{\partial k_{h}}=u_{z}^{h} f_{2}^{h} t_{h}>0, \frac{\partial v^{h}}{\partial y_{1 h}}=\lambda_{h}, \quad \frac{\partial v^{h}}{\partial \varepsilon_{h}}=-\lambda_{h} l_{h} .
$$

If households are assumed to have identical preferences and production functions, differences in second earner labour supplies are driven by $w_{2 h}$, productivities $k_{h}$ and price $p_{h}^{*}$, where the latter depends on the household's choice of quality $q_{h}^{*}$ given the exogenous market relationship $p\left(q_{h}\right)+\tilde{\varepsilon}$. This contrasts with the standard work-leisure model in which the only variable creating acrosshousehold heterogeneity would be $w_{2 h}$.

\subsection{Empirical Specification}

We present the results of numerical simulations of optimal second earner labour supplies using functional forms that are nested within a system in which the household's utility function is

$$
u_{h}=x_{h}^{\gamma}+z_{h}^{\delta} \quad h=1, \ldots, H
$$

for $\gamma, \delta \in(0,1)$ and child care outcomes $z_{h}($.$) are given by the CES production$ function

$$
z_{h}=\kappa\left[\beta_{h}\left(k_{h} t_{h}\right)^{\rho_{h}}+\left(1-\beta_{h}\right)\left(q_{h} b_{h}\right)^{\rho_{h}}\right]^{1 / \rho_{h}}
$$

where $\beta_{h}<1, \kappa$ is a scaling factor, and the parameter $\rho_{h}$ determines the elasticity of substitution between second earner and bought in child care, $1 /\left(1-\rho_{h}\right)$. In the simulations we allow the production coefficient $\rho_{h}$ to have an exogenous stochastic component $\eta_{h}$, so that $\rho_{h}=\bar{\rho}+\eta_{h}, \eta_{h} \gtreqless 0$. This is the equivalent to assuming random preference heterogeneity in the standard literature, but has the advantage of allowing preferences to be assumed identical, thus facilitating welfare comparisons, as is important for most policy applications of the model.

\section{Data}

We present results for two numerical simulations, labeled Model 1 and Model 2 , in which we select values for $\rho_{h}, k_{h}, q_{h}$ and $p_{h}$ that generate female labour supplies that broadly match the data for a sample of two-parent families in the early child rearing years. The sample is drawn from the Australian Bureau of Statistics (ABS) 2010 Survey of Income and Housing (SIH). Couples are selected on the criteria that the family has at least one preschool or primary school child present, the primary earner is employed for at least 30 hours per week, neither

\footnotetext{
${ }^{15}$ In a static model such as this we do not take account of other motives for $l_{h}>0$ when $w_{2 h}<p_{h}$, such as for example investment in maintaining work-related human capital and access to the labour market. See Apps and Rees (2009) for further discussion.
} 
partner reports negative incomes, both partners are aged between 20 and 60 years, and primary earnings are above the 10th percentile. The primary earner is defined as the partner with the higher earnings, and is the male partner in around 90 per cent of records in the sample. The sample contains 1998 records.

\subsection{Heterogeneity}

Table 1 presents the data means of primary earnings by quintiles of primary income for the selected sample. ${ }^{16}$ The table also reports the data means of second earnings and hours of market work within each primary income quintile. To highlight the heterogeneity in second earner labour supplies across the primary income distribution, we split the sample of second earners within each quintile according to hours of work. We label households in which the second earner works below median hours as type $\mathrm{H} 1$ and those in which she works at or above median hours as type H2. ${ }^{17}$ The data means of second hours in each quintile of the full sample and of each type are reported in the table.

Table 1 about here

To test the extent to which the observed heterogeneity in hours might be driven by the second wage, we estimate a wage equation with a Heckman correction for selectivity bias for each quintile and compare predicted wage rates. We find no significant wage gap until quintile 3 , where the predicted wage of the $\mathrm{H} 2$ type is 2 per cent above that of the $\mathrm{H} 1$ type. The gap rises to around 4 per cent in quintile $5 .^{18}$

\subsection{Household Income: Potential for Ranking Errors}

Table 2 presents data means of household earnings by quintiles of household income and reports the means of second earnings within each quintile. The strong positive correlation between household income and second earnings in the first four quintiles of the table reflects both the shape of the primary earnings distribution and the high degree of heterogeneity in second hours.

Tables 2 about here

Primary earnings track the primary wage profile, which rises slowly up to around the 80th percentile and thereafter rises steeply. Consequently, in a ranking by household income the location of a low wage household can change dramatically when the second partner switches from home to market work. Consider, for example, a single-earner family with an income of $\$ 65,000$ for full time work. The upper income limit of quintile 1 in Table 2 is $\$ 70,252$ and therefore the family will be located in that quintile. The lower limit of quintile 4 is

\footnotetext{
${ }^{16}$ Primary income is defined as that of the partner with the higher private income. For details of the income sources included in private income, see Australian Bureau of Statistics (2011).

${ }^{17}$ Median hours across primary income quintiles 1 to 5 are $672,960,1056,960$ and 864, respectively.

${ }^{18} \mathrm{It}$ is of interest to note that when household type is defined on second earner employment status, the wage predicted for the part-time employment category is above that for the full time and non-participant categories.
} 
$\$ 118,987$. When the second parent goes out to work for the same income as the first, the family will be re-ranked to quintile 4 . If the family has a preschool child much of the after tax second income may be spent on child care, in addition to the associated costs of being in the workforce.

Under a system of progressive individual taxation, the $\mathrm{H} 2$ household in which both partners earn the same income pays twice as much tax as the H1 household with the same wage rates. Under a progressive joint income tax, the $\mathrm{H} 2$ household pays more than twice as much tax.

Table 2 reports the ordering of household types, $\mathrm{H} 1$ and $\mathrm{H} 2$, by quintiles of household income. When we switch to a ranking defined on household income we find that $\mathrm{H} 1$ households are strongly concentrated in the lower quintiles, as indicated graphically in Figure 1.

Figure 1 about here

\subsection{Wage Distributions}

The simulations are based on a percentile distribution of primary wage rates obtained by smoothing the distribution of gross wage rates computed from the data on hours and earnings of the primary earner. ${ }^{19}$ The distribution is shown graphically in Figure 2.

Figure 2 about here

Given the close match between the predicted wage rates of $\mathrm{H} 1$ and $\mathrm{H} 2$ second earners, we simplify the simulations by assuming assortative matching, with the second wage rising uniformly with the primary wage as depicted in Figure 2. This allows us to focus entirely on non-wage sources of heterogeneity in the labour supply of second earners. ${ }^{20}$

\subsection{Household Income and Home Child Care}

With overall annual hours close to 1800 the second earner in the H2 household is, on average, employed approximately full time, working 35 hours per week or 7 hours per day of a 5 day working week. The second earner in the H1 household with overall annual hours of 277 is, on average, employed part time, working around 5 hours per week or 1 hour per day of a 5 day working week. In the simulations to follow, the time constraint for the second earner is set at 10 hours per day, which implies that in the $\mathrm{H} 2$ household she allocates an average of 3 hours per day to home child care and in the H1 household, approximately 9 hours per day to home child care.

Figure 3 plots the $\mathrm{H} 1$ and $\mathrm{H} 2$ profiles of household income and the imputed value of time allocated to home child care based on the data means for hours and a time constraint of 10 hours/day for the second earner and of 8 hours/day

\footnotetext{
${ }^{19} \mathrm{~A}$ two-step smoothing procedure is applied using lowess smoothing. We first smooth the distribution of hours, recalculate the wage rate in each percentile, and then smooth the results.

${ }^{20}$ While demographic characteristics differ on average, with the $\mathrm{H} 1$ type having more children in the younger age groups, nevertheless there are many households with identical wage rates and demographic characteristics making very different labour supply decisions.
} 
for the primary earner. It is evident from the profiles that household income will track household welfare if we assume that the longer hours of home child care provided by type $\mathrm{H} 1$ make no significant contribution to family welfare.

Figure 3 about here

\section{Simulations}

All households are assumed to have the same preferences. Labour supply profiles matching the data for $\mathrm{H} 1$ and $\mathrm{H} 2$ are simulated as deviations from a reference, base case optimal allocation of 5 hours of the 10 hour time constraint. This reference is defined by setting $\beta=0.5$ and $\kappa=2.0$ in both models, and $\rho_{h}$ in Model 1 and $k_{h}$ and $p_{h}$ in Model 2 to values that generate 5 hours as the optimum. Results are presented for $\gamma, \delta=0.9$ in the household utility function in (10).

\subsection{Model 1}

Model 1 is a stylised representation of the family labour supply model that is standard in the literature, whether "unitary" or "collective", with the assumptions that are typically introduced when the model is estimated on data sets with missing information on home productivity. In this literature it is usual to treat market child care not as a time input but as a part of the numeraire consumption good with price therefore normalised to 1, while setting the price of home child care (under the label "leisure") equal to the wage. To replicate the effects of this (in our view quite erroneous) modelling strategy under the theoretical approach we are adopting here, we set $k_{h}=1$ and $q_{h} b_{h}=y_{2 h}$. Since, in the standard model, the wage represents productivity in a linear production technology producing $x$, the latter is equivalent to a normalisation that sets $p_{h}=\pi q_{h}=w_{2 h}$, with $\pi$ normalised to $1 .{ }^{21}$ For the value of $\beta$ above, the production function in (11) can be written as

$$
z_{h}=\kappa \beta^{1 / \rho_{h}}\left[t_{h}^{\rho_{h}}+\left(q_{h} b_{h}\right)^{\rho_{h}}\right]^{1 / \rho_{h}}
$$

for $\rho_{h}, h=1,2$.

The reference labour supply of 5 hours of market work is optimal for $\rho_{h}=0$, $h=1,2$, that is, for the Cobb-Douglas case. Since all households with the same wage rates make the same labour decisions for a given value of $\rho_{h}$ there is no heterogeneity in hours other than that driven by the wage. Household welfare tracks household income but there is no re-ordering of households across the wage distribution when ranked by household income because the assumed low productivity of home child care impacts equally on the welfare of all households

\footnotetext{
${ }^{21}$ Note that the only change we have made to the standard model is to place the expenditure of $y_{2 h}$ in a production function rather than leaving it in the consumption variable $x$ of the utility function. This has the advantage of moving heterogeneity from preference to production parameters and therefore of ruling out the non-transparency of the disclaimer that welfare comparisons are not possible.
} 
in a given percentile, and not unequally as indicated in Figure $3,{ }^{22}$ because they make the same time use decisions.

The solution for $\rho_{h}$ that yields an optimal labour supply of 7 hours per day is $\rho_{2} \approx 0.23$, which implies that home and bought in care tend to be substitutes for the $\mathrm{H} 2$ household. An optimal labour supply of 1 hour per day can be generated by setting $\rho_{1} \approx-2.38$, implying that home and bought-in care are close complements for the $\mathrm{H} 1$ household. To capture the tendency towards higher labour supplies across the middle percentiles, we introduce a small degree of variation in these parameter values across the distribution.

The model yields a welfare ranking in which $\mathrm{H} 1$ households are concentrated in the lower percentiles of household utility, as illustrated graphically by the histogram in Figure 4(a) showing the distribution of the two types by quintiles of household utility. Their quintile ordering closely matches that of household income due to the assumed asymmetry in the productivities of home and market time, introduced by setting $k_{h}=1$ and $q_{h}=w_{2 h}$, with $w_{2 h}$ significantly greater than one. Under these assumptions child care output, $z$, is much lower for type H1 than for type H2, as depicted in Figure 4(b).

Figure 4(a) and (b) about here

With a lower output of $z$, the price of child care, $p_{z}$, is much higher for type H1. These output and price differences have an effect similar to that of omitting H1's implicit expenditure on home child care from household income - the contribution of women at home becomes invisible. The model illustrates the unrealistic assumptions required to generate a welfare ranking that supports joint taxation, and therefore gender discrimination, on distributional grounds.

\subsection{Model 2}

In Model 2 household types at a given wage pair have the same production technology. We can therefore drop the $h$ subscript on the parameter $\rho$ and write the child care production function as

$$
z_{h}=\kappa \beta^{1 / \rho}\left[\left(k_{h} t_{h}\right)^{\rho}+\left(q_{h} b_{h}\right)^{\rho}\right]^{1 / \rho}
$$

Consistent with evidence of a positive relationship between child outcomes and maternal human capital, the productivity of the second earner's time input to child care is assumed to be a strictly increasing function $k_{h}=k_{h}\left(w_{2 h}\right)$. Similarly, given a positive relationship between parental investment in children and household resources, the quality of bought in care is assumed to be a strictly increasing function $q_{h}=q_{h}\left(w_{2 h}\right)$. We assume symmetry in the productivity of home child care time and the quality of bought in care by setting $k_{h}=q_{h}$. Under this setting, a labour supply choice of 5 hours per day is optimal for all values of $\rho$. Household utility is defined on wage rates and therefore on full income.

\footnotetext{
${ }^{22}$ Note, however, that in a model of the household as a small economy as in Apps (1982), progressive joint taxation widens the net of tax gender wage gap and will therefore increase intrafamily inequality unless there are offsetting lump sum transfers.
} 
The observed heterogeneity in $\mathrm{H} 1$ and $\mathrm{H} 2$ hours at a given second wage is simulated by first selecting a value for $\rho$ that implies home and bought in care are close substitutes, an assumption that is plausible where the focus of bought in care is child minding rather than early learning and there is a high degree of heterogeneity in second earner labour supply. ${ }^{23}$ We then introduce exogenous variation in the price of bought in care, $p_{h}$, for a given quality, $q_{h}$.

We find that the hours data are closely matched when we set $\rho \approx 0.9$, with a small degree of variation to capture the concavity of second earner labour supply across the wage distribution, and we assume a distribution of $\tilde{\varepsilon}$ such that the price of bought in child care of a given quality varies by 15 per cent above and 10 per cent below the reference price, $p_{h}$. The histogram in Figure 5(a) illustrates graphically the close ranking of the two types by household utility under these settings. Despite the gap between household incomes, the utilities of H1 and $\mathrm{H} 2$ are almost identical at each primary wage because there is only a very small gap between child care output $z_{h}$, as indicated in Figure 5(b), and price $p_{h}$. The result is that both household types tend to be equally well-off at a given wage pair even though they have very different household incomes.

Figure 5(a) and (b) about here

Alternatively we can specify a model that introduces a matching variation in the productivity of home time instead of in the price of bought in care. It is straightforward to show that, in this case, H1 becomes the slightly betteroff household because the partner providing care at home has a slightly higher productivity at a given wage.

\section{Conclusions}

The aim of this paper is to challenge the assumption that household income is a reliable indicator of a household's standard of living, and to argue that policies based on that assumption effectively amount to a form of gender bias. The assumption is shown to be entirely unwarranted in an economy where households exhibit a high degree of heterogeneity in second earner labour supply at given wage rates and demographics.

We develop this proposition formally by first constructing a household model which explicitly takes into account household production, in the form of child care, together with a time constraint which recognises that bought in time must replace parental time in child care. ${ }^{24}$ However, we have also sought to emphasise that this alone is not enough. Indeed, the standard model can be interpreted as implicitly having a household production function which can be incorporated into a kind of reduced form utility function. Then, as our simulations of Model

\footnotetext{
${ }^{23}$ When child care is learning and development focused, the two time inputs are likely to be complements, with households making very simular time use choices. The gap between the $\mathrm{H} 1$ and $\mathrm{H} 2$ hours profiles is not consistent with this assumption.

${ }^{24}$ This apparently trivial fact, which has far-reaching conclusions for the characterisation of the household optimum, has been ignored so far in the literature, where it is usual to assume that the bought in child care input is a consumption good. See for example Blundell et al. (2005), Cherchye et al. (2012).
} 
1 show, explaining heterogeneity of second earner labour supply by varying the elasticity of substitution between domestic and market child care inputs, equivalent in this reduced form to varying the utility of "leisure", preserves the monotonicity of the relationship between household income and welfare. On the basis of this it would be possible to argue that introducing household production "makes no difference".

However, we show that a more substantive and empirically relevant innovation is to introduce across-household variation in the productivity/quality of home and market child care inputs and their prices. In this case it is easy to show that there can be large errors involved in interpreting a ranking of households defined on household income as implying the same ranking in terms of the achieved standard of living. As the indirect utility function generated by the general model shows, the real indicators of household living standards are the values of the wage pairs of primary and second earners, ${ }^{25}$ the price of bought in market child care, and the productivity or quality of both parental and market child care, where the latter are in general positively correlated with wage rates. We have shown that this gives a very different ranking to that based on household income.

An important implication of this analysis is that it provides a critique of the increasingly prevalent practice of basing taxation and child payments on household as opposed to individual incomes. In several countries this practice has resulted in tax rates on second earners, overwhelmingly women earning low to average incomes, that are well above the highest marginal rates in the formal tax system. It is in this sense, we argue, that joint tax systems constitute a significant form of gender bias.

\section{References}

[1] Almond, D, and J Currie (2011), "Human Capital Development Before Age Five", in O Ashenfelter and D Card (eds), Handbook of Labor Economics, Vol 4, Part B, 1315-486.

[2] Apps, P (1982), "Institutional Inequality and Tax Incidence", Journal of Public Economics, 18, 217-42.

[3] Apps, P, and R Rees (1988), "Taxation and the Household", Journal of Public Economics, 35, 355-69.

[4] Apps, P, and R Rees (2009), Public Economics and the Household, Cambridge: Cambridge University Press.

[5] Apps, P, and R Rees (2010), "Family Labour Supply, Taxation and Saving in an Imperfect Capital Market", Review of Economics of the Household, $8,297-323$.

\footnotetext{
${ }^{25}$ Since primary earners do not exhibit such a high degree of heterogeneity in working hours, primary income is a good proxy for the primary earner's wage.
} 
[6] Australian Bureau of Statistics (2011), "Household Expenditure Survey and Survey of Income and Housing", User Guide, Australia 200920, Catalogue No. 6503.0.

[7] Becker, G (1965), "A Theory of the Allocation of Time", Economic Journal, 75(299), 493-517.

[8] Blundell, R, P-A Chiappori and C Meghir (2005), "Collective Labor Supply with Children", Journal of Political Economy, 113(6), 1277-306.

[9] Blundell, R, and T MaCurdy (1999), "Labor Supply: A Review of Alternative Approaches", in O Ashenfelter and D Card (eds), Handbook of Labor Economics, vol III. North-Holland, Amsterdam, 1560-1693.

[10] Boskin, MJ, and E Sheshinski (1983), "Optimal Tax Treatment of the Family: Married Couples", Journal of Public Economics, 20, 281-297.

[11] Cherchye, L, B De Rock and F Vermeulen (2012), "Married with Children: A Collective Labor Supply Model with Detailed Time Use and Intrahousehold Expenditure Information", American Economics Review, 102(7), 3377-3405.

[12] Feldstein, M, and D Feenberg (1996), "The Taxation of Two-Earner Families", in M Feldstein and J Poterba (eds), Empirical Foundations of Household Taxation, University of Chicago Press, Chicago, 39-75.

[13] Lundborg, P, A Nilsson and D Rooth (2012), "Parental Education and Offspring Outcomes: Evidence from the Swedish Compulsory Schooling Reform". IZA DP\# 6570.

[14] Mirrlees, J, S Adam, T Besley, R Blundell, S Bond, R Chote, M Gammie, P Johnson, G Myles and J Poterba (2011), Tax by Design, Oxford University Press.

[15] Munnell, A (1980), "The Couple versus the Individual under the Federal Personal Income Tax", in H Aaron and M Boskin (eds), The Economics of Taxation, The Brookings Institution, 247-280.

[16] Rosen, H (1977), "Is It Time to Abandon Joint Filing", National Tax Journal, 30, 423-428.

[17] Stern, N (1976), "On the Specification of Optimum Income Taxation", Journal of Public Economics, 6(1-2), 123-162. 
Tables and Figures:

Table 1 Primary income quintiles

\begin{tabular}{|l|c|c|c|c|c|c|}
\hline Quintile & $\mathbf{1}$ & $\mathbf{2}$ & $\mathbf{3}$ & $\mathbf{4}$ & $\mathbf{5}$ & All \\
\hline Primary earnings pa & 45131 & 60736 & 77198 & 97865 & 181556 & 92497 \\
\hline Second earnings pa & 17171 & 22515 & 28985 & 32749 & 35260 & 27342 \\
\hline H1* second hours pa & 149 & 279 & 393 & 353 & 210 & 277 \\
\hline H2** second hours pa & 1586 & 1855 & 1863 & 1885 & 1791 & 1797 \\
\hline
\end{tabular}

${ }^{*} \mathrm{H} 1$ : household with $2^{\text {nd }}$ earner working below median second hours. ${ }^{* *} \mathrm{H} 2$ : household with $2^{\text {nd }}$ earner working above median second hours

Table 2 Household income quintiles

\begin{tabular}{|l|c|c|c|c|c|c|}
\hline Quintile & $\mathbf{1}$ & $\mathbf{2}$ & $\mathbf{3}$ & $\mathbf{4}$ & $\mathbf{5}$ & All \\
\hline Household earnings pa & 55281 & 82045 & 105813 & 139354 & 255059 & 127510 \\
\hline Second earnings pa & 4484 & 18110 & 25832 & 38203 & 50107 & 27342 \\
\hline H1* \% & 87.8 & 58.5 & 38.8 & 31.5 & 33.4 & 50.0 \\
\hline H2** \% & 12.2 & 41.5 & 61.2 & 68.5 & 66.6 & 50.0 \\
\hline
\end{tabular}

${ }^{*} \mathrm{H} 1$ : household with $2^{\text {nd }}$ earner working below median second hours. ${ }^{* *} \mathrm{H} 2$ : household with $2^{\text {nd }}$ earner working above median second hours

Figure 1 Household income ranking

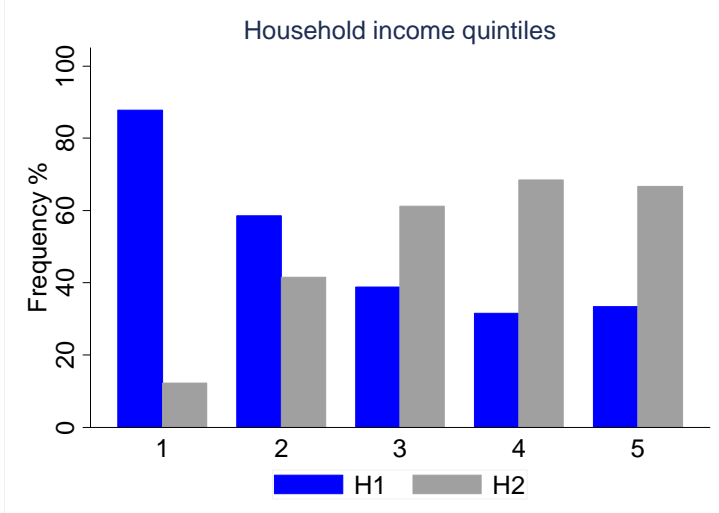

Figure 2 Percentile wage distributions

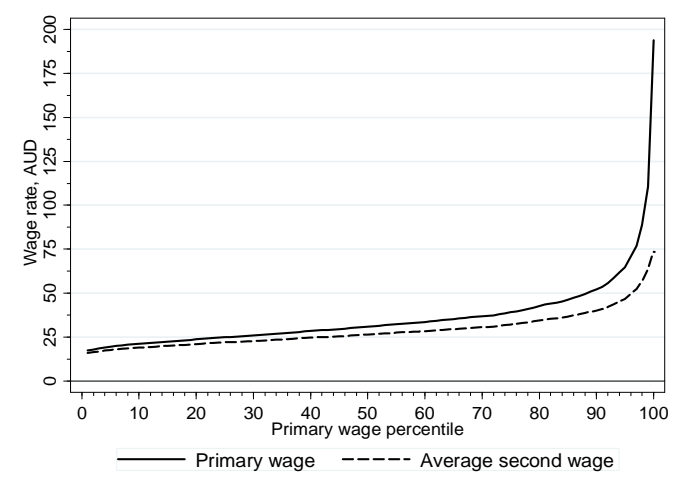


Figure 3 Household income and imputed expenditure on home child care

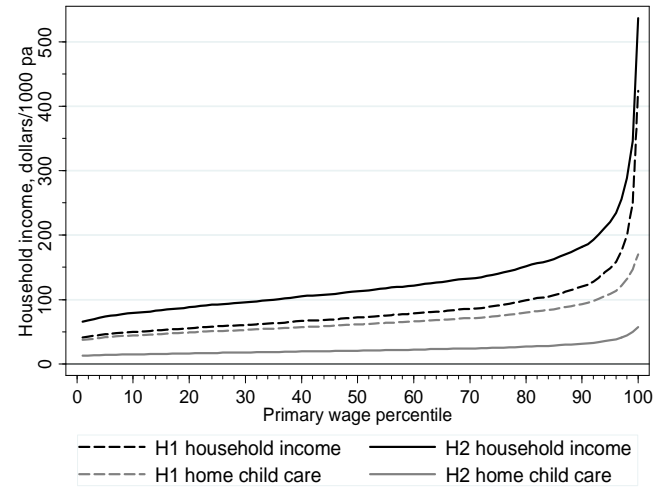

\section{Figure 4}

(a) Model 1: Welfare ranking

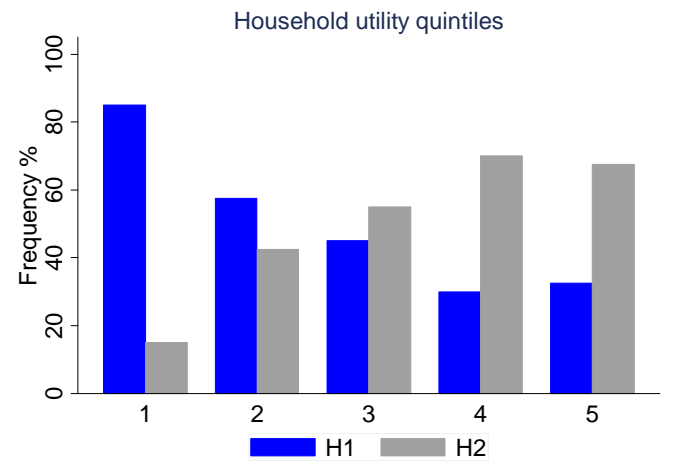

Figure 5

(a) Model 2: Welfare ranking

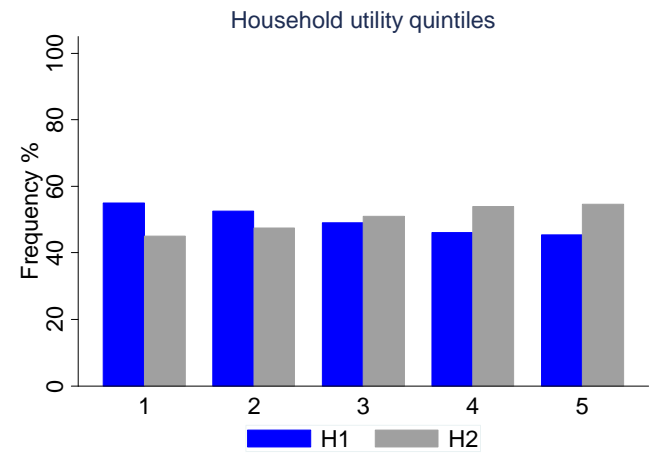

(b) Model 1: Child care output, z

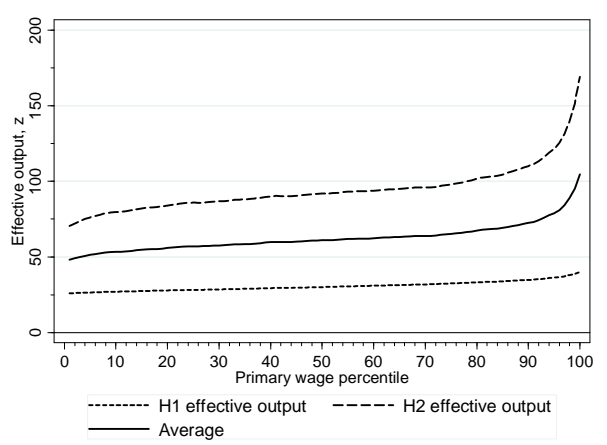

(b) Model 2: Child care output, z

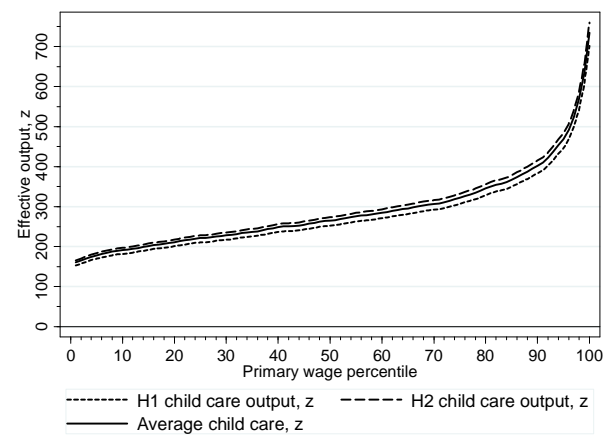

